Article

\title{
Problematic Internet Use among Youths
}

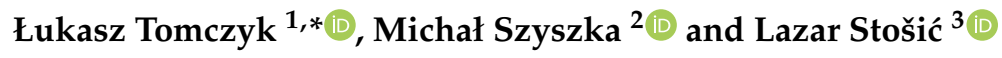 \\ 1 Institute of Educational Science, Pedagogical University of Cracow, 30-060 Cracow, Poland \\ 2 Faculty of Applied Sciences, WSB University, 41-300 Dabrowa Gornicza, Poland; mszyszka@wsb.edu.pl \\ 3 The Association for the Development of Science, Engineering and Education, 17500 Vranje, Serbia; \\ lazarstosic@yahoo.com \\ * Correspondence: lukasz.tomczyk@up.krakow.pl; Tel.: +48-503-738-988
}

Received: 13 May 2020; Accepted: 9 June 2020; Published: 15 June 2020

\begin{abstract}
Problematic Internet Use (PIU) has of late come to the major attention of researchers of risky behaviours. For parents and teachers in turn, the various pathological forms of Internet use have become more and more noticeable. In recent years, the operationalisation of the term PIU has also been discussed and attempts to measure its various phenomena have been made. In our study, we used the quantitative method-a diagnostic survey designed on the basis of a tool of the Supreme Audit Office and Scientific and Academic Computer Network (Naukowa i Akademicka Sieć Kompureowa NASK), The survey was conducted in the first half of 2017 in Poland, among 3569 adolescents (median 16, SD =1.28). The purpose of the research was to investigate the scale of PIU among Polish youths. For most young people, PIU is a major social problem. The majority also declare that more than half of their friends have problems with using electronic media (smartphones and the Internet in particular). On the basis of the data collected, it is estimated that $60 \%$ of adolescents use media in a functional way, whereas $40 \%$ of young electronic media users show visible PIU symptoms, of which $5 \%$ do so at a destructive level (all symptoms). Gender does not co-occur with PIU; however, family structure (where both parents are present), the setting of rules for the use of electronic media, and the place of residence are all protective factors. There is a need for constantly improved tools for measuring PIU, as well as preventive programs focused on developing self-control and helping young people understand their own emotions.
\end{abstract}

Keywords: PIU; problematic internet use; pathological internet use; internet addiction; IAD; Poland; youths; adolescent

\section{Introduction}

The saturation in our lives of new media and the continued development of networked services influence educational processes. The literature presents two extreme positions that emphasise either the risks or the opportunities that result from the common use of electronic devices. The opportunity paradigm assumes that through ICT (Information and Communication Technologies), youths and adults can enrich their lives, have quick access to information, learn without limitations, develop their interests, save time, and generally benefit in many other ways. The risk paradigm assumes that new technologies have activated many risk areas that are particularly hazardous for people with low digital literacy: children, youths, and digital immigrants [1-3]. The risk paradigm within which the pedagogical (and related) research is conducted, greatly emphasises the negative aspects of using digital media. It stands in opposition to the opportunities paradigm, which focuses on the positive effects of introducing ICT in the learning and teaching process. Two examples of research areas within the risk paradigm are Internet Addiction (IAD) and Problematic Internet Use (PIU). Among the numerous online threats that people might encounter, the most noticeable in recent years are 
IAD-related issues accompanied by other important risky behaviours like: dangers resulting from online relationships, exposure to dangerous content (e.g., pornography), the disclosure of personal data, cyberbullying, sexting, hoaxes and fake news, Internet fraud that leads to economic losses, and digital piracy. Out of all the above-mentioned threats, many diagnostic surveys and reports list IAD as the most serious one $[4,5]$. Unfortunately, when analysing the literature on problems related to the use of ICT, we encounter information noise and data smog. For example, there are numerous publications that address the misuse of new technologies, in which IAD, PIU, online gaming, and gambling are very often treated as being equal [6]. Suggesting such equality between these disorders forces a wider discussion on the scale of these phenomena and the attendant diagnostic and coexisting factors [7].

This text is an attempt to present PIU among adolescents: According to many researchers, this group is at particular risk of engaging in PIU [8]. An analysis of PIU not only highlights its coexisting features but also the wider context related to the interpretation of this phenomenon by young people.

The investigation of PIU is connected with the growing saturation in our daily professional and leisure activities with new media. With media convergence, it is also possible to observe a change in the style of ICT use. This is expressed by an increase in the amount of time spent online, a loss of self-control when using new media, negative consequences in the domain of education (a decrease in the quality of social interactions, concentration problems, lower grades, family conflicts, and so forth), and other related problems [9-11]. The diagnosis of the scale of PIU among adolescents is crucial not only in the context of basic research and any discussion over unclear diagnostic criteria, but most of all because it allows the development of adequate and effective preventive programmes and the removal of negative stereotypes about this age group [12,13]. The analyses and results presented herein should be of benefit to the stakeholders (educators, teachers, parents) and the designers of education and health policies affected by the consequences of PIU.

In this text, Problematic Internet Use will be defined as the excessive and/or improper use of the Internet, which may cause psychological, social, academic, and/or professional problems [14] (Laconi et al., 2019). Due to the aforementioned definitional chaos, the next subchapter presents the similarities and differences between the two most frequent terms used to characterise one of the most often discussed forms of risky behaviour mediated by digital media.

What is new in this paper is that the scale of PIU is presented using studies in a large population. In Central Europe, analyses of this type are rarely conducted among extended samples. Furthermore, the text joins the discussion over the scale of the phenomenon and the sociodemographic factors which coexist with PIU and enables, based on the data collected, designing preventive measures addressed to adolescents [15].

\section{Theoretical Framework}

\subsection{International Research Results on PIU}

The vast majority of young people see both the impact and prevalence of PIU. This situation fits into a general academic and common discussion about the ways in which networked media are used. The aspects of PIU connected with the use of mobile phones occupy a special place among the different types of threats. The literature defines this problem as 'nomophobia'. According to $70 \%$ of adolescents, nomophobia is a social challenge. It is also worth pointing out that in recent years in Poland, younger and younger kids have begun to regularly use phones. Today, the average age of initiation for regular phone use is 9.2 years for primary school students [16]. Both the popularity and popularisation of mobile phones and, consequently, the longer time spent using convergent devices, are natural processes in the information society $[17,18]$; however, as in the case of other new media, digital literacy is required to ensure that any use of such devices is safe [19]. It is worth emphasising that young people see nomophobia as a social problem that is much more important than, for example, gaming addiction, something that is included in the DSM- 5 classification. Despite being on the official 
list of behavioural addictions, gaming addiction [20], and gambling [21] still provoke discussions as to their definition, diagnosis, intervention, and media prevention methods. Thus, even though young people acknowledge the importance of PIU, there are many doubts at an academic level as to the clear classification of issues relating to IAD.

Like other age groups, adolescents recognise PIU as a social problem. The general opinion regarding the importance of PIU in other age groups is connected with seeing this phenomenon as prevalent among young people. Young people declare that nomophobia and IAD are the most noticeable phenomena of those being discussed. The high visibility of nomophobia is also a result of more and more frequent discussions in the (traditional) media, school preventive programs, and conversations at home about the threats posed by new media. These activities fit into the negative paradigm of media pedagogy [22] and raise awareness of the threats one faces in the digital world.

Mobile phones have become our main communication and entertainment tools. Nomophobia may often be misinterpreted as the intense and intentional use of new media [23,24]. However, it is easy to identify when there is no access to the device and classic symptoms of addiction occur (constantly thinking about mediated activities, lying to others to gain access, giving up other activities in favour of using the device, and many other symptoms mentioned in the introduction).

In order to diagnose any e-threat, it is worth taking into account the intensity of the relevant PIU factors, the social functioning of the person, and the wider economic and cultural context. The evolution of services available in the information society and, consequently, the changing limits of constructive and problematic use of electronic media, force us to develop ever more sensitive and effective diagnostic tools $[25,26]$.

The foundations of Internet addiction and other types of behavioural addictions have many features in common. The too frequent use of devices and services may lead to addiction [27]. We can identify Internet addiction as an example of the overuse of new technologies, but this concept is the subject of an ongoing discussion due to the unclear and questionable diagnostic criteria that have led to methodological discrepancies in the study of this area. Despite using different indicators to measure IAD, the results are often interpreted as an extension of the PIU concept $[28,29]$. PIU and IAD are sometimes treated as synonyms in the literature [30]. However, it is worth pointing out that IAD also covers gambling and gaming, while PIU applies the criteria of addiction but does not co-occur with clear disease stages. In addition, unlike IAD, PIU does not lead to stigmatisation but rather suggests there is a behaviour that differs from the standard use of online devices. The term 'addiction' as used to describe online risky behaviours suggests a disease, whereas PIU is more vague and constantly re-defined.

In presenting the research results, we use the term PIU. It covers such elements as nomophobia (addiction to mobile phones), gaming addiction, Internet addiction, computer addiction, and online gambling. In order to identify the different PIU factors, the latter part of the test refers to IAD co-occurrence.

The Foundation Dbam o Mój Zasięg lists the following symptoms of nomophobia: having the phone always at hand, including while sleeping; frequently checking the phone (including networked services like SNS); the inability to imagine life without a phone; being fully accessible to others via social media; the urge to get the phone back if it is left somewhere; the urge to find a connection when out of range of the phone network; using the phone regardless of the time and situation; struggling with self-control; being seen by others as someone who is always 'in touch' [16], as well as the specific emotional consequences that derive from these symptoms (e.g., a greater sense of security, an inner urge to reply immediately to messages, anxiety when the battery charge is low or empty; the feeling of missing something important when the phone is turned off, or feeling discontented when there are limits applied to phone use; anxiety or nervousness when the phone cannot be accessed). Symptoms of nomophobia also include negative consequences: lower concentration span, sleep deprivation, neglecting duties, and using the phone in inappropriate situations.

Indicators also include states of fatigue resulting from intense use: the need for peace and quiet, or the need to limit the use of the phone, to switch the phone off and be totally unavailable, or to stop 
being permanently in touch. Another important criterion is the frequency of phone use and related situations, such as: using the phone when bored, spending a noticeably longer time using the phone, the sense of time being wasted using new technology, and more and more time being spent solving problems through the use of the phone [16]. Many of the above-listed predictors for nomophobia are connected with other Internet-related behavioural addictions, e.g., compulsive buying, infoholism, or IAD in general. In certain forms of PIU, predictors interfere with one another in terms of time, self-control, the neglect of responsibilities, being overwhelmed, feedback from others, extended time spent interacting with media, attention becoming absorbed by media, using the phone in almost every situation, sight problems, neglecting offline relationships, forgetting about meals, reduction in the basic physiological needs like eating and sleep, psychosomatic symptoms (headaches and dizziness), and loss of a sense of time (e.g., being late for work or school). Addictions caused by electronic media are inter-related. This is proved, for example, by the high correlation between the uncontrolled use of Facebook and high results in tests measuring IAD [31].

The definitions of PIU and IAD cover a range of common factors like: deceiving loved ones in order to stay online, neglecting family and vocational/school responsibilities, problems with concentration when offline, negative emotions when logged off, and positive emotions when reconnecting to the online world [32-34]. The above-mentioned factors occur in different PIU measuring tools, and there is a high probability that with the growth of one symptom, others will also increase. Thus, PIU is a phenomenon of multiple factor connections [35].

The team led by Lin et al. [36] defines PIU in the context of phone addiction in a more synthetic way. They think symptoms should be noticeable for at least three months and involve: the inability to refrain from using the phone, low mood or irritability, using the phone longer than intended, failed attempts to quit using certain media, prolonged duration of use, using the phone despite noticing the negative consequences for mental or physical health, using the phone in inappropriate situations (while driving a car or crossing a street), and negative changes in peer or work relationships resulting from using the medium. DSM indicators, measuring for instance gambling, may be adopted as a universal PIU criterion. Within this criterion we can identify: the level of preoccupation, tolerance growth, withdrawal, avoiding responsibilities and relationships, an increasing desire to use, deception, theft, problems with family and peer relationships, and the inability to solve problematic situations [37]. Most of these criteria have some common elements regarding: self-control, emotions, family and peer relationships, and the negative consequences of reduced offline activity in order to stay online.

There are several research reports on IAD and PIU available in the Polish and international subject literature, but the documents contain data that have no common methodological grounds (a lack of standardised diagnostic tools). The tests used to collect the data are based on similar criteria for measuring ICT addiction, but they use different scales, cohorts, and methods of collecting data, or they classify adolescents who use technologies in alternately constructive and destructive ways [38-40]. Therefore, it is hard to compare the results, both from a geographical and a time-related perspective. In other words, the multitude of approaches and, in consequence, multitude of tools based on different factors and criteria force us to review the approaches taken and the results of the research. For this reason, in this chapter we have chosen to refer to the most recent studies that show the Central European and global perspectives.

Studies conducted using a large sample of adolescents in Spain $(n=40,955)$ show that PIU affects $16.3 \%$ of the young population. The persons particularly vulnerable to PIU are those who use various networked services intensively and those without parental control exercised over them [41]. The research in Turkey ( $\mathrm{N}=6116$ adolescents between 12 and 18 in Istanbul) show that only $2.9 \%$ of the young respondents have all of the PIU symptoms. However, in this group as much as $61 \%$ of the adolescents declared they were constantly online because they did not have a better alternative offline [42]. The lack of a hobby and long-term passion or the lack of active time spent in the family environment are risk factors that trigger PIU [43]. The Chinese research, in turn, also referring to a population of adolescents $(\mathrm{N}=2160)$, emphasises the importance of not only parental control over 
the use of ICT but also the level of education of the parents and the place of living. Respondents living in urban areas and whose parents have a low level of education struggle more often with PIU in the family [44]. Studies conducted in Japan among 100,050 young people revealed that $8.1 \%$ of the respondents showed PIU symptoms. It is also noticeable that risk taken offline is related to PIU. For example, young people who regularly smoke or have some experience in this area struggle much more often with PIU than adolescents who do not smoke [45]. The results of German research using a representative sample of 1744 teenagers aged 14-17 clearly suggest that the way in which the family functions is a factor protecting against PIU. The study did not show significant differences in PIU according to gender [46].

PIU is a phenomenon, which coexists with specific risk factors. Based on research conducted in the US ( $N=205$, age 12-20, psychiatric hospital patients), an increase in PIU was always connected with cyberbullying or suicide attempts during the last year. Youths with explosive and developmental disorders obtained much higher results regarding PIU. Though they are not causative, these results certainly underline the correlation between mental diseases and unfavourable conditions in the family, and of PIU as one of the accompanying phenomena [47].

The analysis of PIU is often narrowed down in the international discussion to Internet mediated risky behaviours. For example, Tsitsika and the team studied young people $(\mathrm{N}=484$ of adolescents $71.2 \%$ boys; $28.8 \%$ girls, $\mathrm{SD}=14.88 \pm 0.55$ years) and noticed that engagement in online gambling leads to higher PIU results [48]. However, we need to be careful when interpreting this type of relationship as both PIU and gambling share common indicators, so in many areas a simple analysis of the correlations confirms the same with the same (e.g., the amount of time spent using digital media and spent gambling will be the same if the gambling is performed through digital media) [49]. Thus, when interpreting PIU, particular attention to the diagnostic criteria must be given, a reflection which would connect the phenomenon with other digital media-related behavioural disorders listed officially as diseases [50].

\subsection{International Research Results on PIU}

For example, a study conducted by the NASK team ( $=1394$ students, 2016) in Polish schools suggests the following image of teenagers who use new technologies intensely: they declare that at home, they are constantly online or log in several times a day $(80 \%)$, and access new technologies for $188.3 \mathrm{~min}$ a day on average through their phones, or for $70.7 \mathrm{~min}$ a day using a laptop [51]. Similar results regarding the period of use can be found in the research by Błachnio: the average time spent daily on using the Internet was $180 \mathrm{~min}$ [52]. Respondents began to use the Internet independently early, most often when they were 8-10 years old (more than $40 \%$ of respondents). There is also a visible shift in activities-from using fixed technologies to mobile solutions, accompanied by extended time spent using electronic media [53]. Teenagers most often recognised the following PIU symptoms: lack of control over time spent on the Internet, negative emotions when offline, logging on in order to improve mood, and neglecting school responsibilities [51].

One of the breakthrough reports on IAD in Poland was that produced by the Supreme Audit Office. Due to the social prevalence of the phenomenon and the lack of relevant preventive measures at different levels, it conducted a complex analysis of institutions and legal grounds, and also performed an initial survey among parents, teachers and students. To summarise the report's conclusions $(\mathrm{N}=772)$, the majority of young people agree that mobile phone and Internet addictions are a serious social problem. Slightly more than half of the students $(53.2 \%)$ say that nomophobia has increased during the last five years, and the same is true for IAD (43.1\%). Parents and teachers appear much more aware of the scale of IAD. As for the respondents' immediate surroundings, 30\% of their colleagues appear to have lost control of how much time is spent online, $21 \%$ do not meet their school requirements, and $31 \%$ use phones during classes when it is forbidden. More than 33\% of the students indicate that half of their peers neglect their passions because they are preoccupied with the Internet [27]. However, these data are based on declarations and observations, rather than standardised test outcomes, and therefore in order to suggest a co-occurrence with PIU, it is necessary to refer to more standardised results. 
A study conducted among 1493 young adults (18-30 years) found that only $0.3 \%$ of respondents have a high IAD coefficient (the tools were developed using K. Young's test) [54]. The data closest to the aforementioned IAD results come from 2015 and reveal that full IAD symptoms are noticeable among $0.45 \%$ of teenagers living in rural areas and among $2.9 \%$ of those living in cities. The research was conducted using the Internet Addiction Questionnaire designed by Potembska and the Internet Addiction Test by Young, and involved 1860 teenagers, aged 17 on average [55]. A study carried out in 2017 among 1191 young people by means of the Internet Addiction Questionnaire highlighted the connection between risky IAD-related behaviours and alcohol consumption. The correlation between online and offline risky behaviours is also visible in the area of Internet pornography and gaming, and regular alcohol consumption by minors correlates with high results in tests measuring IAD [56]. We find slightly different results in a study conducted in 2015 by a Warsaw team who used Young's Diagnostic Questionnaire (YDQ). Based on data collected from 376 students aged 14-19, the group of adolescents affected by PIU seems to be larger-up to $11.6 \%$, whereas $8.2 \%$ are at risk [57]. A similar result, around $11 \%$ of the whole population of young people being at risk of PIU, can be found in a study by Ryszard Poprawa who used a standardised tool-the Test of Problematic Use of The Internet, designed after IAT by K. Young [58]. In the years 2015-2016, the Foundation Dbam o Mój Zasięg that specialises in studies into nomophobia, collected data from over 22,000 students. The results indicate that young people use mobile devices much more often than PCs or laptops, phones are definitely more often used for entertainment, more than $1 / 3$ of young people cannot imagine life without a phone, and $10 \%$ use their phone once or a few times a day to post photographs, including selfies, in SNS. Between $2 \%$ and $3 \%$ of adolescents show the full symptoms of phone addiction [16].

The different scales of PIU and IAD are visible not only when different tools are applied, but also when the thresholds of constructive and problematic media use are defined differently. The differing results obtained when using standardised tools are also caused by differences resulting from geographical and cultural conditions [59].

\section{Materials and Methods}

\subsection{Research Problems}

With consideration to the different ways of measuring PIU, a methodology anchored in the risk paradigm of media pedagogy in quantitative approach was used for the research. For this purpose, the PIU-related hypotheses formed by the Polish Supreme Audit Office (NIK, 2016) were adopted. One main objective and two complementary objectives were set. The main objective was to investigate the scale of PIU and the factors that differentiate this phenomenon. An additional question was asked about the perception of the scale of PIU among teenagers from the perspective of seeing this problem among their peers, and their evaluation of PIU as a social problem. The study adds to the discussion about the reasonableness of identifying PIU as a new type of addiction, and is a continuation of the research into risky behaviours in social media among Polish youths [60-62].

To summarise, the main research objective is formulated as follows:

- What is the scale of PIU among adolescents?

- The issue itself consists of several detailed problems:

- How do adolescents interpret the importance of PIU among their peers?

- Which of the PIU predictors occurs most frequently in the sample?

- What is the distribution of PIU results among adolescents?

- How do independent variables (place of residence, gender, financial status of the family, family structure, school grades) coexist with PIU?

- What is the relationship between the components that define PIU?

- What percentage of young people belong to the high risk group? 


\subsection{Sampling and Sample Characteristics}

The analysis is based on questionnaires collected from 3569 respondents. There were over four thousand questionnaires initially, but more than five hundred were rejected due to errors (e.g., incomplete answers, double answers, data missing in the metric). The survey was conducted in the first half of 2017 in Poland, in the voivodships (administrative regions): małpolskie (Lesser Poland), podkarpackie (Subcarpathia), and ślaskie (Silesia). The sampling frame was taken from the Centre of Educational Information (Centrum Informacji Oświatowej). The survey was carried out by external interviewers, in compliance with the ethical principles of social research. Respondents gave their consent to participate in the survey and were informed about the voluntary and anonymous character of the survey, as well as its purposes. Consent was also obtained from school directors and teachers who were responsible for the students during the survey. Some schools requested direct feedback on PIU in order to develop their own prevention programs. The data collected herein allow us to draw some conclusions regarding the youth in the selected regions. However, given the previous research into the risky behaviours in the Internet conducted in Poland [49], the data can be generalised for the whole population of the young people in Poland.

The age of respondents was between 14 and 18 years, with an average of 16.01, median of 16, and SD $=1.28$. There were $1598(44.77 \%)$ boys and $1971(55.23 \%)$ girls. The sample structure according to place of residence was as follows: villages $(60.07 \%)$, a city with a population exceeding $200,000(16.45 \%)$, a town with population up to $50,000(15.21 \%)$, a town with a population of 50,000-100,000 $(5.41 \%)$ and a city with a population of 100,000-200,000 (2.86\%). The majority of the respondents reported that their family lived at an average level $(55.87 \%)$, was well-off $(38.08 \%)$, or lived modestly $(6.05 \%)$ The vast majority lived with: mother (95.01\%), father (79.43\%), and siblings $(72.54 \%)$. The students interviewed studied at: lower-secondary school (41.38\%), technical school (26.93\%), upper-secondary school (29.34\%), and vocational school (2.35\%).

\subsection{Research Tool Structure}

The research tools were triangulated. In order to study PIU in schools, a questionnaire developed by the Supreme Audit Office was used. It consisted of four Yes/No questions, in which respondents evaluated the importance of: overusing smartphones, computers, the Internet, and computer games (NIK, 2016, pp. 71-75).

To correlate how PIU is perceived in peer groups, another tool developed by the NIK [27] was used. The respondents were asked to evaluate, in a 7-degree Lickert scale (from no one to everyone), the scale of addiction to smartphones, the Internet, computer, and online games among their closest friends. The internal test coherence was 0.792 .

The tool to investigate the scale of PIU was designed using a test developed by the Research and Academic Computer Network (NASK, Naukowai Akademicka Sieć Komputerowa), a research institute supervised by the Ministry of Digital Affairs. The tool was taken from the study Nastolatki 3.0 [53] p. 15 and enables the self-evaluation of PIU in terms of: self-control when using new media, negative emotions when offline and extreme positive emotions that follow logging back on, giving up meals and sleep in order to be online, failing to complete school responsibilities, neglecting passions and meetings with friends in the real world in order to continue activities online, and lying to parents in order to have access to the online space. Each item was characterised in a 5-degree Lickert scale (from "it has never happened" to "it happens up to a few times a day"). The tool is highly internally coherent (Alpha Cronbach $=0.854$ ). It was designed and validated by a team of researchers who are representatives of the social sciences (pedagogy and psychology), and is available as a research report. The tool was tested during the studies in the representative sample of youths. It was developed by the national research institute that focuses on digital safety and digital literacy development [53]. The thresholds in the tool for functional use, selected symptoms of PIU, and pathological use were set in accordance with K. Young's tool $[63,64]$. The author is aware that the thresholds may be questionable; assuming the points of reference based on the scores and the three groups of users from K. Young's typology 
provide an opportunity to have a clear overview of the phenomenon of PIU and a discussion over the diagnostic criteria.

Additionally, the tool included a metric to obtain such independent variables as: gender, age, place of residence, family economic status, behaviour grades and school grades, family characteristics in the context of parental supervision of the use of electronic media. As a whole, the tool shows a very high inner coherence of 0.831 .

\subsection{Data Analysis}

Due to the diagnostic nature of the research, we focused on presenting the distribution of the factors related to PIU and the respondents' evaluation of PIU. For this purpose, we used descriptive statistics. In order to present the correlations between the factors, a linear correlation coefficient was used. An analysis of the correlations between the sociodemographic features and the numeric variables was conducted using one-way variance analysis $(F)$ with additional confidence level $(p)$ activated. When looking at the heterogeneity of the sample, cluster analysis (k-means method) was applied. All the calculations were performed in STATISTICA 13 software.

\section{Results}

\subsection{Evaluation of PIU and Its Presence among Peers}

When analysing the answers, it is worth pointing out that the respondents' observations are similar for both the importance of the problem of PIU and observations about this phenomenon. Young people emphasise that the vast majority of their peers show symptoms of PIU when it comes to using mobile phones and the Internet. According to the respondents, computer overuse is less intense among their peers, with roughly half having problems with gaming (see Table 1).

Table 1. Frequency of Problematic Internet Use Questionnaire (PIU) in the closest peer group.

\begin{tabular}{|c|c|c|c|c|c|c|c|c|c|c|c|c|c|c|c|c|}
\hline \multirow{2}{*}{$\begin{array}{l}\text { In Your Opinion, How } \\
\text { Many of Your Class } \\
\text { Colleagues }\end{array}$} & \multicolumn{2}{|c|}{ No One } & \multicolumn{2}{|c|}{ Minority } & \multicolumn{2}{|c|}{$\begin{array}{c}\text { Less than } \\
\text { Half }\end{array}$} & \multicolumn{2}{|c|}{ Half } & \multicolumn{2}{|c|}{$\begin{array}{c}\text { More } \\
\text { than Half }\end{array}$} & \multicolumn{2}{|c|}{ Majority } & \multicolumn{2}{|c|}{ Everyone } & \multicolumn{2}{|c|}{$\begin{array}{c}\text { Hard to } \\
\text { Say }\end{array}$} \\
\hline & $\mathbf{N}$ & $\%$ & $\mathbf{N}$ & $\%$ & $\mathbf{N}$ & $\%$ & $\mathbf{N}$ & $\%$ & $\mathbf{N}$ & $\%$ & $\mathbf{N}$ & $\%$ & $\mathbf{N}$ & $\%$ & $\mathbf{N}$ & $\%$ \\
\hline excessive use of the Internet & 177 & 4.96 & 181 & 5.07 & 259 & 7.25 & 283 & 7.93 & 404 & 11.32 & 499 & 13.98 & 1177 & 32.97 & 177 & 4.96 \\
\hline excessive use of the computer & 353 & 9.89 & 234 & 6.55 & 506 & 14.17 & 652 & 18.26 & 673 & 18.85 & 485 & 13.59 & 521 & 14.59 & 353 & 9.89 \\
\hline
\end{tabular}

There is an observable linear correlation between the evaluation of certain PIU components as problematic and recognising PIU in one's own school environment $(r=0.349, p<0.001)$. There are also several interesting correlations with how PIU is perceived. The data show that a lack of parental control strengthens the tendency to be aware of PIU in one's own environment $\mathrm{F}(2,3566)=12.092$, $\mathrm{p}=0.00001$ ( $\eta 2$ partial $=0.006 ; \lambda=28.86 ; \mathrm{P}=0.99$ ). The frequency of conversations about online threats also correlates with an awareness of PIU F $(4,3564)=2.3373, \mathrm{p}=0.05315$ ( $\eta 2$ partial $=0.003$; $\lambda=12.68 ; \mathrm{P}=0.82)$. The bigger the town/city, the more respondents are aware of $\operatorname{PIU} F(4,3564)=5.6318$, $\mathrm{p}=0.00016$ ( $\eta 2$ partial $=0.005 ; \lambda=22.02 ; \mathrm{P}=0.97$ ). Girls recognise the phenomenon to a slightly greater extent than boys do $\mathrm{F}(1,3567)=36.881, \mathrm{p}=0.00000(\eta 2$ partial $=0.011 ; \lambda=48.16 ; \mathrm{P}=1.00)$. The financial status of the family does not affect the way in which PIU is seen $(F(2,3566)=0.08254$, $\mathrm{p}=0.92077(\eta 2$ partial $=0.0001 ; \lambda=0.59 ; \mathrm{P}=0.09))$, nor does the type of school attended by the respondent $(\mathrm{F}(3,3565)=1.5427, \mathrm{p}=0.2013(\eta 2$ partial $=0.001 ; \lambda=8.01 ; \mathrm{P}=0.65))$.

\subsection{PIU Self-Assessment among Polish Teenagers}

The most common and consistent PIU symptoms to occur among the respondents are losing control over how much time is spent online, and an elevated sense of frustration, and to a lesser degree 
giving up sleep and neglecting school duties. The least frequent PIU symptoms were forgetting about meals, skipping after-school activities, avoiding meetings with friends, and lying to parents in order to be able to use electronic media (see Table 2).

Table 2. Distribution of PIU indicators.

\begin{tabular}{|c|c|c|c|c|c|c|c|c|c|c|c|c|}
\hline \multirow[t]{2}{*}{ Have You Ever? } & \multicolumn{2}{|c|}{$\begin{array}{l}\text { It Has Never } \\
\text { Happened }\end{array}$} & \multicolumn{2}{|c|}{$\begin{array}{c}\text { Once or } \\
\text { Several } \\
\text { Times a Year }\end{array}$} & \multicolumn{2}{|c|}{$\begin{array}{l}\text { Once or } \\
\text { Several Times } \\
\text { a Month }\end{array}$} & \multicolumn{2}{|c|}{$\begin{array}{c}\text { Once or } \\
\text { Several } \\
\text { Times a Week }\end{array}$} & \multicolumn{2}{|c|}{$\begin{array}{c}\text { Once or } \\
\text { Several } \\
\text { Times a Day }\end{array}$} & \multicolumn{2}{|c|}{ MEDIANSD } \\
\hline & $\mathbf{N}$ & $\%$ & $\mathbf{N}$ & $\%$ & $\mathbf{N}$ & $\%$ & $\mathbf{N}$ & $\%$ & $\mathbf{N}$ & $\%$ & & \\
\hline $\begin{array}{l}\text { V1. Stayed online longer } \\
\text { than you intended? }\end{array}$ & 601 & 16.84 & 583 & 16.34 & 739 & 20.71 & 884 & 24.77 & 762 & 21.35 & 2 & 1.38 \\
\hline $\begin{array}{l}\text { V2. Felt frustrated when } \\
\text { the Internet broke or you } \\
\text { had no access to it? }\end{array}$ & 720 & 20.17 & 993 & 27.82 & 835 & 23.40 & 545 & 15.27 & 476 & 13.34 & 2 & 1.30 \\
\hline $\begin{array}{l}\text { V3. Tried to improve your } \\
\text { mood by using the } \\
\text { Internet? }\end{array}$ & 730 & 20.45 & 637 & 17.85 & 707 & 19.81 & 743 & 20.82 & 752 & 21.07 & 2 & 1.43 \\
\hline $\begin{array}{l}\text { V.4 Given up a meal in } \\
\text { order to use the Internet? }\end{array}$ & 2749 & 77.02 & 415 & 11.63 & 195 & 5.46 & 126 & 3.53 & 84 & 2.35 & 0 & 0.92 \\
\hline $\begin{array}{l}\text { V. } 5 \text { Given up sleep in order } \\
\text { to use the Internet? }\end{array}$ & 2091 & 58.59 & 664 & 18.60 & 403 & 11.29 & 251 & 7.03 & 160 & 4.48 & 0 & 1.15 \\
\hline $\begin{array}{l}\text { V. } 6 \text { Neglected school } \\
\text { responsibilities in order to } \\
\text { use the Internet? }\end{array}$ & 1659 & 46.48 & 838 & 23.48 & 517 & 14.49 & 350 & 9.81 & 205 & 5.74 & 1 & 1.23 \\
\hline $\begin{array}{l}\text { V. } 7 \text { Neglected other school } \\
\text { activities in order to use the } \\
\text { Internet? }\end{array}$ & 2513 & 70.41 & 540 & 15.13 & 257 & 7.20 & 147 & 4.12 & 112 & 3.14 & 0 & 1.00 \\
\hline $\begin{array}{l}\text { V. } 8 \text { Neglected other } \\
\text { after-school activities in } \\
\text { order to use the Internet? }\end{array}$ & 2672 & 74.87 & 470 & 13.17 & 222 & 6.22 & 107 & 3.00 & 98 & 2.75 & 0 & 0.93 \\
\hline $\begin{array}{l}\text { V.9 Given up meetings with } \\
\text { friends in order to use the } \\
\text { Internet? }\end{array}$ & 2744 & 76.88 & 496 & 13.90 & 187 & 5.24 & 73 & 2.05 & 69 & 1.93 & 0 & 0.83 \\
\hline $\begin{array}{l}\text { V. } 10 \text { Lied to your parents } \\
\text { in order to use the Internet? }\end{array}$ & 2470 & 69.21 & 647 & 18.13 & 234 & 6.56 & 112 & 3.14 & 106 & 2.97 & 0 & 0.96 \\
\hline
\end{tabular}

Turning to the three thresholds for electronic media use identified by K. Young, the biggest group is the group of functional users, that is, respondents with occasional, selected symptoms of PIU-60\% of young Internet users. About $40 \%$ of young users of electronic media show more than two full PIU symptoms, out of which $5 \%$ use the Internet at a destructive level (these respondents have all or almost all of the symptoms of PIU) (see Table 3).

Table 3. PIU thresholds.

\begin{tabular}{|c|c|c|c|c|c|c|}
\hline & Number & $\begin{array}{l}\text { Cumulative } \\
\text { Number }\end{array}$ & $\begin{array}{l}\text { Percentage } \\
\text { of Relevant }\end{array}$ & $\begin{array}{c}\text { Cumulative } \\
\% \text { of } \\
\text { Relevant }\end{array}$ & $\begin{array}{c}\% \text { of } \\
\text { General } \\
\text { Cases }\end{array}$ & $\begin{array}{l}\text { Cumulative } \\
\% \text { of the } \\
\text { General }\end{array}$ \\
\hline functional $<=0$ points & 176 & 176 & 4.935 & 4.93 & 4.93 & 4.93 \\
\hline functional $<=5$ points & 897 & 1073 & 25.13 & 30.06 & 25.13 & 30.06 \\
\hline functional $<=10$ points & 1056 & 2129 & 29.58 & 59.65 & 29.58 & 59.65 \\
\hline selected symptoms of $\mathrm{PIU}<=15$ points & 740 & 2869 & 20.73 & 80.38 & 20.73 & 80.38 \\
\hline selected symptoms of $\mathrm{PIU}<=20$ points & 379 & 3248 & 10.61 & 91.00 & 10.61 & 91.00 \\
\hline selected symptoms of $\mathrm{PIU}<=25$ points & 166 & 3414 & 4.65 & 95.65 & 4.65 & 95.65 \\
\hline pathological $<=30$ points & 86 & 3500 & 2.40 & 98.06 & 2.40 & 98.06 \\
\hline pathological $<=35$ points & 31 & 3531 & 0.86 & 98.93 & 0.86 & 98.93 \\
\hline pathological $<=40$ points & 38 & 3569 & 1.06 & 100.00 & 1.06 & 100.00 \\
\hline
\end{tabular}

Those respondents who declared that their parents set and maintained rules for using new media received much lower results in the PIU test: $\mathrm{F}(2,3566)=40.863, \mathrm{p}=0.0000$ ( $\eta 2$ partial $=0.027$; $\lambda=115.63 ; \mathrm{P}=1.00$ ). At the same time, teenagers living in big cities have a much higher PIU ratio than adolescents from small towns and villages: $F(4,3564)=12.075, p=0.00000(\eta 2$ partial $=0.011$; $\lambda=46.81 ; \mathrm{P}=0.99)$. Gender does not suggest a tendency towards $\mathrm{PIU}(\mathrm{F}(1,3567)=0.08212, \mathrm{p}=0.77446$ $(\eta 2$ partial $=0.000 ; \lambda=0.22 ; \mathrm{P}=0.075))$; nor does family financial status $(\mathrm{F}(2,3566)=1.3698, \mathrm{p}=0.25428$ $(\eta 2$ partial $=0.000 ; \lambda=2.09 ; \mathrm{P}=0.23))$. PIU decreases visibly when respondents live with their mother 
$(\mathrm{F}(1,3567)=14.809, \mathrm{p}=0.00012(\eta 2$ partial $=0.003 ; \lambda=15.42 ; \mathrm{P}=0.97))$, father $(\mathrm{F}(1,3567)=16.670$, $\mathrm{p}=0.00005(\eta 2$ partial $=0.005 ; \lambda=20.71 ; \mathrm{P}=0.99))$, and siblings $(\mathrm{F}(1,3567)=23.751, \mathrm{p}=0.00000$ ( $\eta 2$ partial $=0.007 ; \lambda=29.20 ; \mathrm{P}=0.99)$ ). PIU is more likely among those living in households of only one parental figure. Living with a grandmother $(\mathrm{F}(1,3567)=1.4790, \mathrm{p}=0.22401$ ( $\eta 2$ partial $=0.000$; $\lambda=1.78 ; \mathrm{P}=0.26)($ and grandfather $(\mathrm{F}(1,3567)=2.0477, \mathrm{p}=0.15252(\eta 2$ partial $=0.000 ; \lambda=2.96$; $\mathrm{P}=0.40)$ ), does not protect against PIU. Students with lower behaviour grades are in a higher risk group $(\mathrm{F}(5,3563)=18.072, \mathrm{p}=0.0000(\eta 2$ partial $=0.023 ; \lambda=101.12 ; \mathrm{P}=1.00))$; the same is true of those with an average grade $(F(4,3564)=10.640, \mathrm{p}=0.00000(\eta 2$ partial $=0.013 ; \lambda=55.32 ; \mathrm{P}=0.99))$-the lower the average, the greater the risk of PIU. Students from upper secondary and technical schools obtained slightly better results in the test measuring PIU than those in lower secondary or vocational school $(\mathrm{F}(3,3565)=6.6154, \mathrm{p}=0.00019(\eta 2$ partial $=0.01 ; \lambda=42.18 ; \mathrm{P}=0.99))$. Age does not co-occur with PIU at all $(\mathrm{r} 2=0.082 ; \mathrm{p}<0.05)$. We can also observe that all of the PIU predictors are inter-related. In each case, there is a stronger or weaker linear correlation. The most visible relationship is between giving up school and after-school activities in order to use ICT, or missing meetings with friends and lying to parents, as well as having a worse mood when offline and a better mood when reconnecting. Another strong relationship is observed in the case of neglecting physiological needs (e.g., sleep, food) in order to stay online. PIU features are inter-related and there are no exceptions here (see Table 4).

Table 4. Correlations between PIU factors.

\begin{tabular}{|c|c|c|c|c|c|c|c|c|c|}
\hline & 2 & 3 & 4 & 5 & 6 & 7 & 8 & 9 & 10 \\
\hline 1. I stayed online longer than I intended & 0.48 & 0.47 & 0.2 & 0.35 & 0.37 & 0.24 & 0.22 & 0.2 & 0.23 \\
\hline 2. I felt frustrated when I was offline & 1 & 0.47 & 0.27 & 0.35 & 0.36 & 0.26 & 0.23 & 0.22 & 0.27 \\
\hline 3. I made myself feel better by going online & & 1 & 0.25 & 0.36 & 0.38 & 0.26 & 0.23 & 0.22 & 0.25 \\
\hline 4. I gave up a meal in order to be online & & & 1 & 0.56 & 0.4 & 0.5 & 0.5 & 0.5 & 0.45 \\
\hline 5. I gave up sleep in order to use the Internet & & & & 1 & 0.53 & 0.48 & 0.45 & 0.43 & 0.45 \\
\hline 6. I gave up school responsibilities in order to stay online & & & & & 1 & 0.58 & 0.45 & 0.37 & 0.43 \\
\hline 7. I gave up other school activities in order to use the Internet & & & & & & 1 & 0.68 & 0.51 & 0.45 \\
\hline $\begin{array}{l}\text { 9. I gave up meetings with friends in order to use the Internet } \\
\text { 10. Lied my parents in order to use the Internet }\end{array}$ & & & & & & & & 1 & 0.51 \\
\hline
\end{tabular}

There may be several explanations for the differing distribution of the results. Considering the distribution of answers with similar values, we can use cluster analysis to divide the cases into clusters. Each cluster contains objects with the same or similar features (located by one another on the diagram, and having similar measures of distance). Cluster analysis shows PIU factors in clusters, thus providing an opportunity to identify homogeneous groups of high risk (see Figure 1).

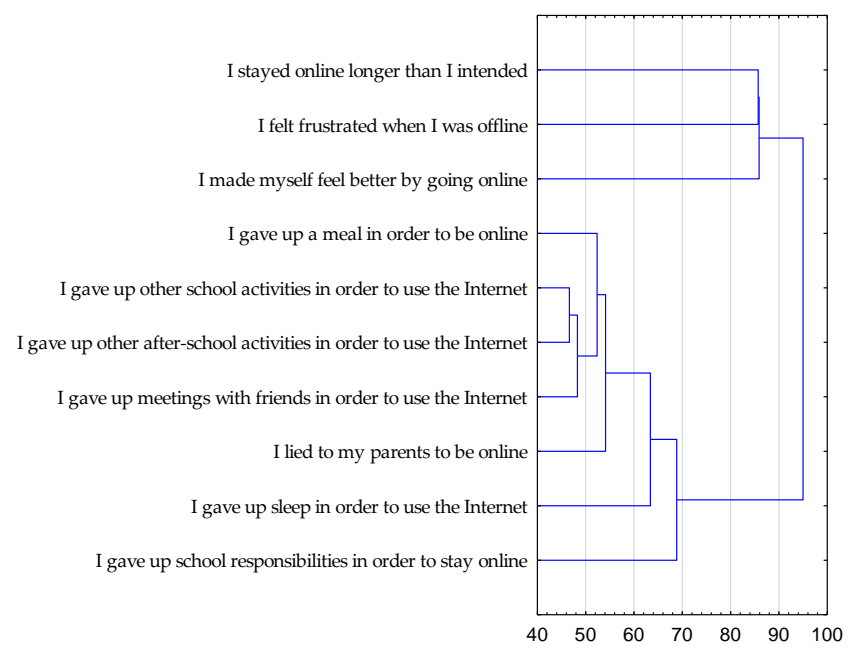

Figure 1. Dendrogram of PIU co-occurrence, developed by single-linkage clustering. 
In data analysis, the Euclidean distance was partially used, as it shows a similarity or difference for certain objects or clusters. Considering Figure 1, which shows the size of the similarities, we can identify 6 groups. To increase the justification for the division, a visualisation with k-means algorithms was used. This method allows us to fully identify and describe each cluster (see Figure 2).

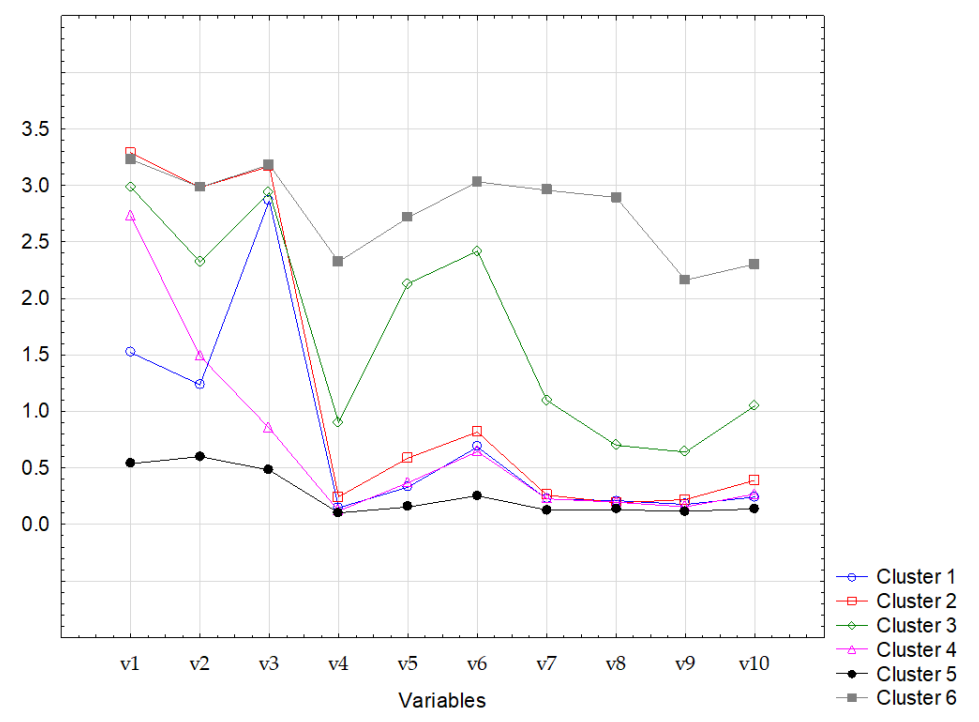

Figure 2. Mean graphs for every cluster.

The assumption of there being 6 groups is confirmed in Figure 2. Based on the above graph, we can observe that there is a group of respondents with a relatively high level of factors suggestive of PIU, as well as groups with high results in a single area but lower in others. There are also two groups with only a few higher factors, whereas the remaining factors are low. Cluster number 5 is of particular interest, as $23.29 \%$ of the respondents show a very low or hardly existing level of PIU risk. The cluster analysis also confirms a low percentage, of between $5-6 \%$, of people with very visible PIU symptoms (Cluster 6) (see Table 5).

Table 5. Number of respondents assigned to certain clusters.

\begin{tabular}{cccccccc}
\hline & Cluster 1 & Cluster 2 & Cluster 3 & Cluster 4 & Cluster 5 & Cluster 6 & Total \\
\hline Count & 656 & 621 & 578 & 634 & 827 & 235 & 3551 \\
Count in $\%$ & $18.47 \%$ & $17.49 \%$ & $16.28 \%$ & $17.85 \%$ & $23.29 \%$ & $6.62 \%$ & 100 \\
\hline
\end{tabular}

Based on the indicators designed in this manner, we can say that in these 6 groups different behaviours are featured and coalesce to form non-homogeneous clusters in many areas. A common feature is a lack of self-control connected with the amount of time spent with new media. Another interesting group (cluster 5-almost one quarter of those surveyed) contains respondents who have not given up their school responsibilities and meals, but participate in the networked media space by giving up sleep. We also need to emphasise cluster 1 , where the most important motivation for engaging with networked activities is the desire to improve one's mood (18.47\%). The cluster analysis reveals that PIU is non-homogeneous, and the contribution of co-occurrence varies. Only in the case of cluster 6 is the share of all factors relatively high.

\section{Discussion}

With reference to the original research problems, it is clear that young people can recognise PIU. The vast majority of the respondents emphasised the fact that PIU is most often connected with the excessive use of smartphones and the Internet and, less frequently, games. The data are coherent with 
the previous findings by NIK, and show that young people, like adults, have observed an increase in PIU among their family and friends. Asked about their peers, they most often say it is their friends who have serious problems with smartphones and Internet overuse. Against the common opinion, the young generation seem able to recognise anomalies in this area. This type of data is of particular importance in terms of prevention and can be a starting point for a discussion with adolescents about the scale of PIU in their age group.

Based on an analysis of the accumulation of PIU factors, we observed that $5 \%$ of the respondents show full PIU symptoms. First, this percentage is consistent with previous analyses in Poland [16,27]. Second, it refutes the myth about the prevalence of the phenomenon in its full intensity. This percentage of young people with all of the symptoms of PIU also forces a reflection on the measuring criteria, including consideration of the changes in the means by which ICT is used or the transformation of services in the information society (like new networked services such as TikTok, which have been steadily growing in popularity among adolescents) [65].

Given the data collected, another specific group requires particular attention: $35 \%$ of the respondents who show several but intense symptoms of PIU. Here, it is also worth discussing the diagnostic criteria such as time spent online or treating Internet use as a priority. Often, both criteria are inaccurate. It seems that asking about the types of activities on the Internet that young people engage in, rather than simply the amount of time spent online, would yield more precise and useable data, since consideration of the type of online activity might indicate the presence or absence of PIU more precisely.

The analysis carried out through the use of the correlation coefficient and the cluster analysis presented two interesting facts. The occurrence of full symptoms of PIU is related to the fact that the diagnostic factors are connected. When one factor occurs, there is a high probability that others will be also present to a large degree. This is particularly noticeable for groups, where about $5-6 \%$ of respondents show all of the factors at a high or very high level (Figure 2).

To understand the phenomenon of PIU in the context of the data presented, we need to refer to other research results and diagnostic criteria. About $60 \%$ of young people use the Internet functionally, showing 2 to 10 PIU factors, whereas $40 \%$ (out of which less than $5 \%$ show all of the symptoms of PIU) use new technologies in a partially destructive or pathological way. The data presented in this paper, showing the distribution of variable features, are in line with the earlier study by M. Deebski $(\mathrm{N}=22,086$, 2015-2016) who observes that up to 3\% of young people show clear symptoms of nomophobia [16], a phenomenon which also shares some characteristics of FOMO [66]. When we look at the data gathered by $\mathrm{R}$. Solecki $(\mathrm{N}=680,2017)$, who also used $\mathrm{K}$. Young's test, we get a picture suggesting that $8.9 \%$ of the respondents are at risk of PIU. Only a small percentage of the respondents reveal full symptoms $[67,68]$. It is also worth recalling the research from 2014-2015 conducted by a team from the University of Rzeszów, using an extended version of K. Young's tool. Based on their data, about $11 \%$ of the teenagers surveyed $(\mathrm{N}=505)$ had several symptoms of IAD [58]. However, when we look at the results of the study by the Research and Academic Computer Network, we can see that the vast majority of teenagers recognised some factors of PIU in themselves [53]. But it needs to be emphasised that the dual scale used in the NASK study does not fully reflect the frequency of behaviours and, thus, may be misleading. Therefore, it is very important that research is conducted using a longitudinal tool that raises no methodological objections and allows us to compare the results. PIU, or Internet addiction, is difficult to present in full, as there are no unambiguous criteria and, thus, there are no tools that include all of the factors agreed upon by researchers of mediated risky behaviours [69]. Due to this difficulty, in many countries including Poland, PIU is not measured continuously in close cohorts, which means there are many opinions about the phenomenon. In addition, with different tools, the thresholds of constructive and pathological use of the Internet change [70].

Regardless of the measurement criteria adopted, the research shows many coherent protective factors. These are characteristics also present in other, geographically or culturally independent societies. One of the universal criteria is parental control [71-73], based on clearly defined and executed 
rules for the use of electronic media at home, the quality of family relationships [74-77], and family structure. The location of residence is another interesting protective factor-correlations suggest that in smaller communities, villages in particular, the scale of PIU decreases. This might be explained by the larger number of household chores that young people living in villages are responsible for (such as the responsibilities connected with helping parents to take care of a farm). Another mediating factor may be the more active engagement of parents and other family members in the young people's lives. This relationship requires further in-depth analysis.

On the basis of the cluster analysis, we can observe that the distribution of answers provided in 2016 [51] is in line with the results presented herein. Many dominant factors remain the same, for example: A lack of control over time spent on the Internet, negative emotions when offline, logging in to improve mood, and neglecting school responsibilities in order to spend more time online [78]. Regardless of the methods used, the analyses reveal these factors to be dominant features of PIU. Modern preventive programs that focus on minimising risky behaviours in the area of behavioural addictions should focus on reinforcing self-control mechanisms, helping young people to understand their own emotions, and creating alternative leisure time activities that are independent of new media [79].

\section{Conclusions}

One of the solutions facilitating longitudinal research into IAD, or PIU is the use of standardised tools with appropriate psychometric parameters. An example of such a tool may be the Polish adaptation of Young's Internet Addiction Test [80], which can be used to study risky behaviours both in large populations and in smaller school communities in order to facilitate the design of preventive programs [81]. Failure to provide a reliable IAD and PIU diagnosis has been observed by the Supreme Audit Office which critically evaluates the system of diagnosing and supporting the youngest users at risk of mediated addictions. The NIK report also suggests that problematic issues should be resolved by two cooperating ministries, the Ministry of National Education and the Ministry of Health, and diagnosed by school directors in cooperation with psychological-pedagogical councils [27]. Unfortunately, until now the postulates presented by the Audit Office have not been met. The difficulty might result from the diversity of diagnostic criteria, as well as the specifics of the developing information society $[82,83]$. Both PIU and IAD are real methodological and educational challenges [84].

Author Contributions: Conceptualization, Ł.T.; methodology, Ł.T.; software, L.S.; validation, Ł.T. and M.S.; formal analysis, Ł.T.; investigation, Ł.T.; resources, M.S.; data curation, X.X.; writing—original draft preparation, Ł.T.; M.S., L.S.; writing——.T.; visualization, Ł.T.; supervision, L.S., M.S.; project administration, Ł.T.; funding acquisition, M.S. All authors have read and agreed to the published version of the manuscript.

Funding: The project is funded under the program of the Minister of Science and Higher Education titled "Regional Initiative of Excellence" in 2019-2022, project number 018/RID/2018/19, the amount of funding PLN $10788423,16$.

Conflicts of Interest: The authors declare no conflict of interest.

\section{References}

1. Wachowicz, J. Information Society in Poland-Similarities and Differences in the Perception of ICT between Generations. Inf. Syst. Dev. Res. Appl. Educ. 2016, 17, 195-204.

2. Eger, L. Technologie Vzdělávání Dospělých/Adult LearnIng Technologies; Západočeská univerzita v Plzni: Plzeň, Czech Republic, 2005.

3. Rozkosz, E.; Siuda, P.; Stunża, G.; Dabbrowska, A.; Klimowicz, M.; Kulczycki, E.; Muszyński, D.; Piotrowska, R.; Sieńko, M.; Stachura, K. Information and Media Literacy of Polish Children according to the Results of "Children of the Net" and "Children of the Net 2.0" Studies. In Information Literacy. Lifelong Learning and Digital Citizenship in the 21st Century: Second European Conference, ECIL 2014, Dubrovnik, Croatia, 20-23 October 2014; Springer: Berlin, Germany, 2014; pp. 263-273. 
4. Orange. Rodzice i Dzieci Wobec Zagrożeń Dzieci w Internecie; Fundacja Orange: Warsaw, Poland, 2016.

5. Kopecký, K.; Szotkowski, R.; Krejčí, V. Rizikové Formy Chování Českých a Slovenských Dětí V Prostředí Internetu; Univerzita Palackého v Olomouci: Olomouc, Czech Republic, 2015.

6. Yellowlees, P.; Marks, S. Problematic Internet Use or Internet Addiction? Comput. Hum. Behav. 2007, 23, 1447-1453. [CrossRef]

7. Kaltiala-HeIno, R.; Lintonen, T.; Rimpelä, A. Internet Addiction? Potentially Problematic Use of the Internet in a Population of 12-18 Year-Old Adolescents. Addict. Res. Theory 2004, 12, 89-96. [CrossRef]

8. Widyanto, L.; Griffiths, M. An Empirical Study of Problematic Internet Use and Self-Esteem. Int. J. Cyber Behav. Psychol. Learn. 2011, 1, 13-24. [CrossRef]

9. Tomczyk, Ł.; Solecki, R. Problematic Internet Use and Protective Factors Related to Family and Free Time Activities among Young People. Educ. Sci. Theory Pract. 2019, 19. [CrossRef]

10. Koronczai, B.; Kökönyei, G.; Griffiths, M.; Demetrovics, Z. the Relationship between Personality Traits, Psychopathological Symptoms, and Problematic Internet Use: A Complex Mediation Model. J. Med. Internet Res. 2019, 21, e11837. [CrossRef]

11. Macur, M.; Király, O.; Maraz, A.; Nagygyörgy, K.; Demetrovics, Z. Prevalence of Problematic Internet Use in Slovenia. Slov. J. Public Health 2016, 55, 202-211. [CrossRef] [PubMed]

12. Kojima, R.; Sato, M.; Akiyama, Y.; ShInohara, R.; Mizorogi, S.; Suzuki, K.; Yokomichi, H.; Yamagata, Z. Problematic Internet Use and Its Associations with Health-Related Symptoms and Lifestyle Habits Among Rural Japanese Adolescents. Psychiatry Clin. Neurosci. 2019, 73, 20-26. [CrossRef] [PubMed]

13. Torres-Rodríguez, A.; Griffiths, M.; Carbonell, X.; Farriols-Hernando, N.; Torres-Jimenez, E. Internet GamIng Disorder Treatment: A Case Study Evaluation of Four Different Types of Adolescent Problematic Gamers. Int. J. Ment. Health Addict. 2019, 17, 1-12. [CrossRef]

14. Laconi, S.; Urbán, R.; Kaliszewska-Czeremska, K.; Kuss, D.; Gnisci, A.; Sergi, I.; Barke, A.; JeromIn, F.; Groth, J.; Gamez-Guadix, M.; et al. Psychometric Evaluation of the Nine-Item Problematic Internet Use Questionnaire (PIUQ-9) in Nine European Samples of Internet Users. Front. Psych. 2019, 10, 136. [CrossRef]

15. Moreno, M.A.; Lauren Jelenchick, B.S.; Cox, E. Problematic Internet Use among US Youth: A Systematic Review. Arch. Pediatr. Adolesc. Med. 2011, 165, 797-805. [CrossRef]

16. Dębski, M. Nałogowe korzystanie z telefonów komórkowych. Gdańsk: Fundacja Dbam o Mój Zasieg; Fundacja Dbam o Mój Zasieg: Gdynia, Poland, 2016.

17. Czerska, I. Pokolenie Head down Jako Konsekwencja Smartfonizacji Spo- Łeczeństwa/The "Head down" Generation as a Consequence of Smartphonization of the Society. Prace Naukowe Uniwersytetu Ekonomicznego we Wrocławiu 2016, 459, 214-221. [CrossRef]

18. Olszak, C.; Ziemba, E. The Information Society Development Strategy on a Regional Level. In Proceedings of the 2009 InSITE Conference 2009, Macon, GA, USA, 12-15 June 2009.

19. Tomczyk, Ł. Digital competences of parents in the matter of electronic threats. SHS Web Conf. 2018, 48, 01004. [CrossRef]

20. Lukavská, K. The Immediate and Long-Term Effects of Time Perspective on Internet Gaming Disorder. J. Behav. Addict. 2018, 7, 44-51. [CrossRef] [PubMed]

21. Van Rooij, A.; Ferguson, C.; Colder Carras, M.; Kardefelt-Winther, D.; Shi, J.; Aarseth, E.; Bean, A.; Bergmark, K.; Brus, A.; Coulson, M.; et al. A Weak Scientific Basis for Gaming Disorder: Let Us Err On the Side of Caution. J. Behav. Addict. 2018, 7, 1-9. [CrossRef] [PubMed]

22. Plichta, P.; Pyżalski, J. Narażenie Uczniów Ze Specjalnymi Potrzebami Edukacyjnymi Na Hazard Tradycyjny I Internetowy Oraz Inne Zachowania Ryzykowne. Niepetnosprawność 2016, 222-242. [CrossRef]

23. Davazdahemami, B.; Hammer, B.; Soror, A. Addiction to Mobile Phone or Addiction through Mobile Phone? In Proceedings of the 49th Hawaii International Conference on System Sciences (HICSS), Koloa, HI, USA, 5-8 January 2016.

24. Young, K. The Digital Drug: Understanding and Treating Mobile Phone Addiction. In Encyclopedia of Mobile Phone Behavior; IGI Global: Hershey, PA, USA, 2015; pp. 780-791.

25. Liu, T.; Potenza, M. Problematic Internet Use: Clinical Aspects. Impulse Control Disord. 2010, $167-181$. [CrossRef]

26. Lam, L. Internet Gaming Addiction, Problematic Use of the Internet, and Sleep Problems: A Systematic Review. Curr. Psych. Rep. 2014, 16, 444. [CrossRef]

27. Nik, Przeciwdziałanie E-Uzależnieniu Dzieci i Młodzieży; Najwyższa Izba Kontroli: Warsaw, Poland, 2016. 
28. Strittmatter, E.; Parzer, P.; Brunner, R.; Fischer, G.; Durkee, T.; Carli, V.; Hoven, C.; Wasserman, C.; Sarchiapone, M.; Wasserman, D.; et al. A 2-Year LongitudInal Study of Prospective Predictors of Pathological Internet Use in Adolescents. Eur. Child Adolesc. Psychiatry 2015, 25, 725-734. [CrossRef]

29. Koenig, J.; Fischer-Waldschmidt, G.; Brunner, R.; Resch, F.; Kaess, M. Zuflucht in Digitalen Welten-Zum Zusammenhang Von Kritischen Lebensereignissen Mit Pathologischem Internetgebrauch im Jugendalter. Prax. Kinderpsychol. KInderpsychiatr. 2016, 65, 494-515. [CrossRef]

30. NegIng, P.; Musa, R.; Kasuma, J.; NegIng, M. Millennial and Internet: A positive behavioral effect of pathological Internet use (PIU). Int. J. Bus. Soc. 2017, 18, 619-631.

31. Błachnio, A.; Przepiorka, A.; Senol-Durak, E.; Durak, M.; Sherstyuk, L. The Role of Personality Traits in Facebook and Internet Addictions: A Study on Polish, Turkish, and Ukrainian Samples. Comput. Hum. Behav. 2017, 68, 269-275. [CrossRef]

32. Lam, L.; Wong, E. Stress Moderates the Relationship Between Problematic Internet Use by Parents and Problematic Internet Use by Adolescents. J. Adolesc. Health 2015, 56, 300-306. [CrossRef]

33. Liu, T. Phenomenology and epidemiology of problematic internet use. In Oxford Handbooks Online; Oxford University Press: Oxford, UK, 2012.

34. Durak, M.; Senol-Durak, E. Which Personality Traits Are Associated with Cognitions Related to Problematic Internet Use? Asian J. Soc. Psychol. 2014, 17, 206-218. [CrossRef]

35. Tokunaga, R.; Rains, S. A Review and meta-Analysis examining conceptual and operational definitions of problematic internet Use. Hum. Commun. Res. 2016, 42, 165-199. [CrossRef]

36. Lin, Y.; Chiang, C.; Lin, P.; Chang, L.; Ko, C.; Lee, Y.; Lin, S. Proposed Diagnostic Criteria for Smartphone Addiction. PLoS ONE 2016, 11, e0163010. [CrossRef] [PubMed]

37. Faregh, N.; Derevensky, J. A Comparative Latent Class Analysis of Endorsement Profiles of DSM-IV Diagnostic Criteria for Problem Gambling Among Adolescents from a Community and a Treatment Sample. Addict. Res. Theory 2011, 19, 323-333. [CrossRef]

38. Arslan, A.; Kırık, A.M.; Karaman, M.; Çetinkaya, A. Digital Addiction in High School and University Students. Int. Peer Rev. J. Commun. Hum. Res. 2015, 8, 34. [CrossRef]

39. Akturk, A.O.; Bulbul, A.E.; Celik, I. Analysis of Relationships between Problematic Internet Use and Attachment Styles. In Proceedings of the EDULEARN17, Barcelona, Spain, 3-5 July 2017.

40. Kern, L.; Acier, D. Adaptation Française De L'Échelle Problematic Internet Use Questionnaire. Évol. Psychiatr. 2013, 78, 357-371. [CrossRef]

41. Gómez, P.; Rial, A.; Braña, T.; Golpe, S.; Varela, J. Screening of Problematic Internet Use among Spanish Adolescents: Prevalence and Related Variables. Cyberpsychol. Behav. Soc. Netw. 2017, 20, 259-267. [CrossRef]

42. Aricak, O.T. Problematic Online Betting Among Turkish Adolescents. J. Gambl. Stud. 2019, 35, 31-45. [CrossRef] [PubMed]

43. Wassiński, A.; Tomczyk, Ł. Factors reducing the risk of internet addiction in young people in their home environment. Child. Youth Serv. Rev. 2015, 57, 68-74. [CrossRef]

44. Yu, L.; Recker, M.; Chen, S.; Zhao, N.; Yang, Q. The Moderating Effect of Geographic Area On the Relationship Between Age, Gender, and Information and Communication Technology Literacy and Problematic Internet Use. Cyberpsychol. Behav. Soc. Netw. 2018, 21, 367-373. [CrossRef]

45. Morioka, H.; Itani, O.; Osaki, Y.; Higuchi, S.; Jike, M.; Kaneita, Y.; Kanda, H.; Nakagome, S.; Ohida, T. Association Between Smoking and Problematic Internet Use Among Japanese Adolescents: Large-Scale Nationwide Epidemiological Study. Cyberpsychol. Behav. Soc. Netw. 2016, 19, 557-561. [CrossRef] [PubMed]

46. Wartberg, L.; Kammerl, R.; Rosenkranz, M.; Hirschhäuser, L.; Hein, S.; Schwinge, C.; Petersen, K.U.; Thomasius, R. The Interdependence of Family Functioning and Problematic Internet Use in a Representative Quota Sample of Adolescents. Cyberpsychol. Behav. Soc. Netw. 2014, 17, 14-18. [CrossRef] [PubMed]

47. Gansner, M.; Belfort, E.; Cook, B.; Leahy, C.; Colon-Perez, A.; Mirda, D.; Carson, N. Problematic Internet Use and Associated High-Risk Behavior in An Adolescent Clinical Sample: Results From a Survey of Psychiatrically Hospitalized Youth. Cyberpsychol. Behav. Soc. Netw. 2019, 22, 349-354. [CrossRef]

48. Tsitsika, A.; Critselis, E.; Janikian, M.; Kormas, G.; Kafetzis, D. Association between Internet Gambling and Problematic Internet Use among Adolescents. J. Gambl. Stud. 2011, 27, 389-400. [CrossRef] [PubMed]

49. Pyżalski, J. Agresja Elektroniczna i Cyberbullying jako Nowe Ryzykowne Zachowania Młodzieży; Oficynawydawniczaimpuls: Kraków, Poland, 2012. 
50. Király, O.; Griffiths, M.; Urbán, R.; Farkas, J.; Kökönyei, G.; Elekes, Z.; Tamás, D.; Demetrovics, Z. Problematic Internet Use and Problematic Online Gaming Are Not the Same: Findings from a Large Nationally Representative Adolescent Sample. Cyberpsychol. Behav. Soc. Netw. 2014, 17, 749-754. [CrossRef] [PubMed]

51. NASK. Raport z badania Nastolatki 3.0.; NASK Instytut Badawczy: Warsaw, Poland, 2017.

52. Błachnio, A.; Przepiórka, A.; Hawi, N. The More You Use Facebook, the More You Risk Becoming Addicted to It? A Study Report. Neuropsychiatry 2016, 6, 80-84. [CrossRef]

53. NASK. Nastolatki 3.0. 2016. Available online: https://akademia.nask.pl/badania/RAPORT\%20\%20Nastolatki\%203.0\%20-\%20wybrane\%20wyniki\%20bada\%C5\%84\%20og\%C3\%B3lnopolskich.pdf (accessed on 10 June 2020).

54. Cudo, A.; Kopiś, N.; Stróżak, P.; Zapała, D. Problematic Video Gaming and Problematic Internet Use among Polish Young Adults. Cyberpsychol. Behav. Soc. Netw. 2018, 21, 523-529. [CrossRef]

55. Pawłowska, B.; Zygo, M.; Potembska, E.; Kapka-Skrzypczak, L.; Dreher, P.; Kędzierski, Z. Prevalence of Internet Addiction and Risk of Developing Addiction As Exemplified By a Group of Polish Adolescents From Urban and Rural Areas. Ann. Agric. Environ. Med. 2015, 22, 129-136. [CrossRef] [PubMed]

56. Zygo, M.; Potembska, E.; Zygo, K.; Stanisławek, A.; Karaś, Ł.; Pawłowska, B. Alcohol Consumption and the Risk of Internet Addiction in Teenagers Aged 13-17 Years Living in the Urban and Rural Areas. Curr. Probl. Psychiatry 2017, 18, 110-119. [CrossRef]

57. Tabak, I.; Zawadzka, D. Loneliness and Internet Addiction of Polish Adolescents. Psychiatr. Psychol. Klin. 2017, 17, 104-110. [CrossRef]

58. Rębisz, S.; Sikora, I. Internet Addiction in Adolescents. Pract. Theory Syst. Educ. 2016, 11, 194-204. [CrossRef]

59. Ferrara, P.; Corsello, G.; Ianniello, F.; Sbordone, A.; Ehrich, J.; GiardIno, I.; Pettoello-Mantovani, M. Internet Addiction: StartIng the Debate on Health and Well-Being of Children Overexposed to Digital Media. J. Pediatr. 2017, 191, 280-281. [CrossRef] [PubMed]

60. Rey, R.D.; Casas, J.A.; Ortega-Ruiz, R.; Schultze-Krumbholz, A.; Scheithauer, H.; Smith, P.; Thompson, F.; Barkoukis, V.; Tsorbatzoudis, H.; Brighi, A.; et al. Structural Validation and Cross-Cultural Robustness of the European CyberbullyIng Intervention Project Questionnaire. Comput. Hum. Behav. 2015, 50, 141-147.

61. Tomczyk, Ł.; Srokowski, Ł.; Wạsiński, A. Kompetencje w Zakresie Bezpieczeństwa Cyfrowego w Polskiej Szkole; Stowarzyszenie Miasta w Internecie: Tarnów, Poland, 2016.

62. Tsitsika, A.; Janikian, M.; Schoenmakers, T.; Tzavela, E.; Ólafsson, K.; Wójcik, S.; Macarie, G.; Tzavara, C.; Richardson, C. Internet Addictive Behavior in Adolescence: A Cross-Sectional Study in Seven European Countries. Cyberpsychol. Behav. Soc. Netw. 2014, 17, 528-535. [CrossRef] [PubMed]

63. Young, K. Internet Addiction Test (IAT); Stoelting: Wood Dale, IL, USA, 2016; ISBN 978-0-9982980-9-2.

64. Young, K.S.; De Abreu, C.N. (Eds.) Internet Addiction: A Handbook and Guide to Evaluation and Treatment; John Wiley \& Sons: Hoboken, NJ, USA, 2010.

65. Stošić, L.; Stošić, I. Perceptions of teachers regarding the implementation of the Internet in education. Comput. Hum. Behav. 2015, 53, 462-468. [CrossRef]

66. Tomczyk, Ł.; Selmanagic-Lizde, E. Fear of Missing out (FOMO) among youth in Bosnia and Herzegovina-Scale and selected mechanisms. Child. Youth Serv. Rev. 2018, 88, 541-549. [CrossRef]

67. Solecki, R. Aktywność Młodzież w Cyberprzestrzeni; Oficyna Wydawnicza Von Velke: Warsaw/Milanówek, Poland, 2017.

68. Mróz, A.; Solecki, R. PostawyrodzicówwobecaktywnoścInastolatków w Internecie w percepcjiuczniów. E-mentor 2017, 4, 1-7.

69. Kuss, D.; Lopez-Fernandez, O. Internet Addiction and Problematic Internet Use: A Systematic Review of Clinical Research. World J. Psychiatry 2016, 6, 143. [CrossRef] [PubMed]

70. Melonashi, E. Theoretical Models Explaining Problematic Internet Use: A Systematic Review. In Proceedings of the INTED2017, Valencia, Spain, 6-8 March 2017.

71. Lin, C.; Lin, S.; Wu, C. The effects of parental monitoring and leisure boredom on adolescents' Internet addiction. Adolescence 2009, 44, 993-1004.

72. Rodríguez-de-Dios, I.; van Oosten, J.; Igartua, J. A Study of the Relationship between Parental Mediation and Adolescents' Digital Skills, OnlIne Risks and Online Opportunities. Comput. Hum. Behav. 2018, 82, 186-198. [CrossRef]

73. Bayraktar, F. Online Risks and Parental Mediation Strategies Comparison of Turkish Children/Adolescents Who Live in Turkey and Europe? Ted Eğitim Ve Bilim 2017. [CrossRef] 
74. Alt, D.; Boniel-Nissim, M. Parent-Adolescent Communication and Problematic Internet Use: The Mediating Role of Fear of Missing Out (FoMO). J. Fam. Issues 2018, 39, 3391-3409. [CrossRef]

75. Wang, W.; Li, D.; Li, X.; Wang, Y.; Sun, W.; Zhao, L.; Qiu, L. Parent-Adolescent Relationship and Adolescent Internet Addiction: A Moderated Mediation Model. Addict. Behav. 2018, 84, 171-177. [CrossRef] [PubMed]

76. Tserkovnikova, N.G.; Shchipanova, D.Y.; Uskova, B.A.; Puzyrev, V.V.; Fedotovskih, O. Psychological Aspects of Internet Addiction of Teenagers. Int. J. Environ. Sci. Educ. 2016, 11, 8846-8857.

77. Wartberg, L.; Aden, A.; Thomsen, M.; Thomasius, R. Zusammenhänge Zwischen Familialen Aspekten und Pathologischem Internetgebrauch bei Jugendlichen. Z. Kinder Jugendpsychiatr. Psychother. 2015, 43, 9-19. [CrossRef]

78. Velickovic, S.; Stosic, L. Preparedness of Educators to Implement Modern Information Technologies in Their Work with Preschool Children. Int. J. Cogn. Res. Sci. Eng. Educ. 2016, 4, 23-30. [CrossRef]

79. Frania, M. Selected Aspects of Media Literacy and New Technologies in Education as a Challenge of Polish Reality. Perspect. Innov. Econ. Bus. 2014, 14, 109-112. [CrossRef]

80. Hawi, N.; Blachnio, A.; Przepiorka, A. Polish Validation of the Internet Addiction Test. Comput. Hum. Behav. 2015, 48, 548-553. [CrossRef]

81. Pyżalski, J. From CyberbullyIng to Electronic Aggression: Typology of the Phenomenon. Emot. Behav. Diffic. 2012, 17, 305-317. [CrossRef]

82. Ziemba, E. Factors Affecting the Adoption and Usage of ICTs within Polish Households. In Proceedings of the 2016 InSITE Conference, Vilnius, Lithuania, 27 June-1 July 2016.

83. Ziemba, E. The ICT Adoption in Enterprises in the Context of the Sustainable Information Society. In Proceedings of the 2017 Federated Conference on Computer Science and Information Systems, Prague, Czech Republic, 3-6 September 2017.

84. FIneberg, N.; Demetrovics, Z.; Stein, D.; Ioannidis, K.; Potenza, M.; Grünblatt, E.; Brand, M.; Billieux, J.; Carmi, L.; King, D.; et al. Manifesto for a European Research Network Into Problematic Usage of the Internet. Eur. Neuropsychopharmacol. 2018, 28, 1232-1246. [CrossRef] [PubMed]

(C) 2020 by the authors. Licensee MDPI, Basel, Switzerland. This article is an open access article distributed under the terms and conditions of the Creative Commons Attribution (CC BY) license (http://creativecommons.org/licenses/by/4.0/). 